\title{
Extraction, Physico-Chemical Characterization and Antimicrobial Screening of the Muscle Lipid of Cuttle Fish (Sepia esculenta) of the Bay of Bengal
}

\author{
M. Al-Amin ${ }^{1}$, M. H. Uddin ${ }^{2, *}$, A. Afrin ${ }^{2}$, K. B. Nath ${ }^{3}$, S. Barua ${ }^{2}$ \\ ${ }^{1}$ Applied Research Laboratory, Department of Chemistry, University of Chittagong, \\ Chittagong 4331, Bangladesh \\ ${ }^{2}$ Department of Applied \& Environmental Chemistry, University of Chittagong, \\ Chittagong 4331, Bangladesh \\ ${ }^{3}$ Institute of Education, Research and Training, University of Chittagong, \\ Chittagong 4331, Bangladesh \\ *E-mail address: mhuddincu@yahoo.com
}

\begin{abstract}
Lipid was extracted from the muscle of Cuttle fish by solvent extraction method and then purified by suitable conventional method. Various physical constants e.g. refractive index, viscosity, specific gravity, crude fat, crude fibre and ash contents and chemical parameters e.g. saponification value, saponification equivalent value, acid value, iodine value, acetyl value, peroxide value, thiocyanogen value, Reichert-Meissl value, Polenske value, Henher value, cholesterol content etc. of the lipid sample have been determined and compared with those of different standard oils. Fatty acids composition of the sample was investigated by Thin Layer Chromatography (TLC) method. The muscle lipid of Cuttle fish was found to contain palmitic acid, stearic acid, linolenic acid and erucic acid respectively with some other unknown fatty acids. Antimicrobial activities of the lipid were tested by standard method and found moderate to potential antibiotic and antifungal property in this lipid. The lipid containing muscle of Cuttle fish was analyzed quantitatively for the determination of percentages of protein and minerals $(\mathrm{N}, \mathrm{P}, \mathrm{K}, \mathrm{Ca})$ contents by modified Kjeldahl method.
\end{abstract}

Keywords: Cuttle fish, Antibacterial, Antifungal, Thin Layer Chromatography, PUFA

\section{INTRODUCTION}

Cuttle fish (Sepia esculenta) is found plenty in the Bay of Bengal but local people are not aware about the importance of this fish and sufficient data on the food value and pharmaceutical aspects are also not available. Many marine fishes are rich in lipids (oil) which provide mainly 16:0 and 18:1 fatty acids including pharmaceutically important $\omega-3$ polyunsaturated fatty acids $(\omega-3 \text {, PUFA })^{1}$. Lipid is important dietary constituents because it has high energy value and contains fat soluble vitamins and essential fatty acids ${ }^{2}$. Fats and oils are the most important lipids found in nature. They are one of the three major food factors needed for human body. Important influence of the fish oil on the serum lipid and 
lipoprotein profiles in human beings was found ${ }^{3}$. They provide concentrated reserve of energy in animal body for maintaining optimum body temperature. One gram of metabolized fat or oil yield $9 \mathrm{kcal}$ of heat ${ }^{4,5}$. Fish fat is characteristically rich in $\omega-3$ long chain poly unsaturated fatty acids (PUFA) making it an important and beneficial diet for mankind in keeping low levels of cholesterol in blood. The $\omega-3$ fatty acid series are abundantly found in marine algae and phytoplankton and also in the marine fishes which eat these marine plants $6,7,8$. Marine fish oils are generally characterized by rather large group of saturated and unsaturated fatty acids, which are commonly associated with triglycerides. Its effect on the lipid profile in normotensive subjects ${ }^{9}$, hypertensive subjects ${ }^{10}$ and patients with nephritic syndrome $^{11}$ have been also mentioned. Present study is about the physico-chemical characterization of the solvent-extracted oil from the muscle of Cuttle fish (Sepia esculenta) of the Bay of Bengal and comparing the results with the data available in literature about pharmacological aspects of Cuttle fish. Performance of the muscle lipid of Cuttle fish against some common microbial species is also reported.

\section{EXPERIMENTAL}

\section{1. Collection of the marine species}

The export quality Cuttle fish was collected from the fish market, Sadarghat, Chittagong and preserved in deep freezer for a few days. The muscle was then separated and preserved until extraction. Only the muscle was kept aside separately for extraction and chemical investigation.

\section{2. Extraction of Lipid}

Oil extraction from muscle of species was carried out by solvent extraction method using acetone and ethyl acetate as solvent. Combined solvent extracted oils were recovered with a rotary evaporator at $45^{\circ} \mathrm{C}$ and dried under flushing with a slow stream of nitrogen gas for the removal of residual solvent.

\section{3. Physical Characterization of the Lipid}

Extracted lipid was used for physico-chemical characterization, microbial studies and for analysis of fatty acids pattern by TLC. The amount of total lipid was determined gravimetrically. Crude fat, crude fibre and ash contents of the muscle of Cuttle fish were determined by standard methods ${ }^{12}$. A weight portion of muscle of Cuttle fish was first dried in an oven at about $100-105^{\circ} \mathrm{C}$ for $4-5$ hours to remove moisture and then burnt into ash in a muffle furnace at about $600{ }^{\circ} \mathrm{C}$ for 4 hours ${ }^{13}$.

The refractive index of the lipid sample was determined by refractometer (Model; DTM-1 Atago Co. Ltd). The specific gravity of the lipid sample was determined by S.G. bottle. The viscosity of the lipid sample was determined by Ostwald's viscometer at $30{ }^{\circ} \mathrm{C}$. Analytical grade chemicals were used and solutions were prepared according to the standard procedure $^{14-16}$.

\section{4. Chemical Characterization}

Many chemical properties of the lipid sample were determined under the specific condition of the standard methods. Saponification value, saponification equivalent value, acid value and percentage of free fatty acid, iodine value, acetyl value ${ }^{17}$, peroxide value ${ }^{18}$, 
thiocyanogen value, Richert-Meissl value and Polenske value ${ }^{19}$, Henher value, Kirschner value, marine oil test, Elaiden test, cholesterol content and quantity of unsaponifiable matter ${ }^{20}$ of the lipid were determined by standard methods.

\section{5. Antimicrobial Screening}

The antimicrobial activity of muscle lipid of Cuttle fish was studied against four bacteria and four fungi. For the detection of antibacterial activities the disc diffusion method $^{21}$ was followed. The antifungal activity was assessed by food poison technique ${ }^{21}$. Nutrient agar (NA) and potato dextrose agar (PDA) were used as basal medium for the test of bacteria and fungi respectively. Chloroform was used as a solvent to prepare desired solution $(10 \%)$ of the lipid sample. Proper control was maintained with chloroform.

\section{6. Estimation of Minerals}

By applying the standard methods, minerals $(\mathrm{N}, \mathrm{P}, \mathrm{K}$ and $\mathrm{Ca})$ of lipid containing muscle were determined.

\section{7. Chromatographic Examinations}

The muscle lipid of Cuttle fish was subjected to TLC examination and its fatty acid composition was identified by comparing the $\mathrm{R}_{\mathrm{f}}$ values of different spots of chromatograms with those of standard fatty acids reported earlier in different solvent systems ${ }^{22,23}$.

\section{RESULTS AND DISCUSSION}

\section{1. Physical Properties}

The amount of total lipid content of Cuttle fish was $20.98 \mathrm{mg} / \mathrm{g}$ of muscle. This may claim valuable demand of Cuttle fish for edible purpose due to their higher lipid level.

The refractive index of muscle lipid of Cuttle fish was found to be 1.4731 at $24{ }^{\circ} \mathrm{C}$ (Table 1). The refractive power of oils or fats varies widely and chiefly governed by the proportion and degree of unsaturation present. It is also an intensive property of any substance. The present result indicates that the muscle lipid from the specimen contained moderate amount of unsaturated fatty acids. This was also supported by its iodine value.

The specific gravity of the lipid solution was determined and was found to be 0.9735 at $30{ }^{\circ} \mathrm{C}$ (Table 1). This sample was found in semisolid condition. From the result of this experiment, we got an idea about the specific gravity of the original lipid.

The viscosity of the lipid solution of the sample was found to be 320.325 milipoise at $30{ }^{\circ} \mathrm{C}$ (Table 1). From the result of viscosity we got an idea about the intermolecular hydrogen bonding in the lipid sample. The present result suggested that there is a few hydroxyl group and few free acid molecules may present in the lipid sample. This observation is supported by low acetyl value and low acid value of the lipid sample. 
Table 1. Physical constants of the muscle lipid of Cuttle fish and other lipid samples.

\begin{tabular}{|c|c|c|c|}
\hline Name of the sample & Refractive index & Specific gravity & Viscosity (mp) \\
\hline Linseed oil & $1.4790-1.4800$ & $0.931-0.938$ & 296.084 \\
\hline Sunflower oil & $1.4655-1.4721$ & $0.924-0.926$ & 331.125 \\
\hline Brain lipid of Kerani Chingri & 1.4748 & 0.9180 & 287.060 \\
\hline Brain lipid of Baghda Chingri & 1.4736 & 0.941 & 303.260 \\
\hline $\begin{array}{c}\text { Liver lipid of Blue Spotted } \\
\text { Fantail Ray }\end{array}$ & 1.4760 & 0.9575 & 325.325 \\
\hline Muscle lipid of Hilsha & 1.4637 & $\ldots \ldots$ & $\ldots \ldots$ \\
\hline Muscle lipid of Cuttle fish & 1.4731 & 0.9735 & 320.325 \\
\hline
\end{tabular}

Crude fat, Crude fibre and ash content of the muscle of Cuttle fish were determined as shown in Table 2.

Table 2. Crude fat, fibre content and ash content of the muscle of Cuttle fish.

\begin{tabular}{|c|c|c|c|}
\hline $\begin{array}{c}\text { Name of the } \\
\text { Sample }\end{array}$ & Crude fat (\%) & Crude Fibre (\%) & Ash content (\%) \\
\hline Muscle of Hilsha & 2.25 & 1.35 & 0.96 \\
\hline Muscle of Cuttle fish & 4.75 & 2.31 & 1.992 \\
\hline
\end{tabular}

\section{2. Chemical Properties}

The saponification value of the muscle lipid of Cuttle fish was found to be 260.87 (Table 3). The Saponification equivalent value of the muscle lipid of Cuttle fish was found to be 215.05 (Table 3). It is a measure of the average molecular weight (chain length) of all the fatty acids present. It allows for comparison of the average fatty acid chain length. The long chain fatty acids found in fats have low saponification value because they have a relatively fewer number of carboxylic functional groups per unit mass of the fat as compared to short chain fatty acids. Saponification equivalent is inversely proportional to the average molecular weight or chain length of the fatty acids present in the fat or oil. The result clearly indicates that the lipid sample contains higher proportion of high molecular weight fatty acids.

The acid value of the muscle lipid of Cuttle fish was found to be 1.78 (Table 3). The percentage of free fatty acid (FFA), as oleic, was calculated from acid value and was found to be 0.89 for the muscle lipid of Cuttle fish (Table 3). Low acid value is an indication of freshness of the oil or fat and suitability of the lipid for edible purpose. The free fatty acid is produced by the hydrolytic decomposition of the oil or fat. The ester value of the sample was found to be 258.77 (Table 3). This value indicates the amount of ester present in the lipid sample. Iodine value (Table 3) gives an estimation of the degree of unsaturation and so, of the relative amounts of unsaturated fatty acids in the triglyceride molecules of the fat or oil. 
Iodine value of the lipid sample was found to be 106.82 (Table 3). This value indicates that the lipid sample contains moderate proportion of unsaturated fatty acids which also maintain the criteria of edible oil and PUFA containing oil which is beneficial for cardiac health ${ }^{24}$.

The Peroxide value of an oil or fat is used as a measurement of the extent to which rancidity reactions have occurred during storage. The double bonds found on fats and oils play a role in autoxidation. Peroxide value of the lipid sample was found to be 109.45 (Table 3) which indicating fair amounts of unsaturated fatty acid content.

The Acetyl value (12.95) of the fish oil (Table 3) indicates low content of free hydroxyl groups in the lipid sample. The Thiocyanogen value of the lipid sample was found to be 54.82 (Table 3). This observation also supports its moderate iodine and peroxide value.

The Titre value (27.5) of the sample (Table 3) indicates that the sample is of fat types which support their semisolid condition at room temperature. The Henher value was found to be 77.98 (Table 3).

This result indicates the higher percentage of water insoluble nonvolatile fatty acids present in the lipid sample. The unsaponifiable matter (1.10) indicates (Table 3) that the lipid contains a good amount of unsaponifiable sterols, tocopherols, vitamins A \& D, hydrocarbons and so on ${ }^{25}$. Polenske value $(0.72)$ and Richert-Meissl value $(0.91)$ of the muscle lipid of Cuttle fish (Table 3) were determined. The result of Polenske value indicates a small content of volatile water but alcohol soluble fatty acids in the lipid sample. RichertMeissel value indicates low content of volatile water soluble fatty acids.

The Kirschner value of the muscle lipid of Cuttle fish as determined was found to be 0.424. These indicate the presence of trace amount of fatty acids in the Reichert-Meissl distillate which form soluble silver salt. The muscle lipid of Cuttle fish was found to form cloudy solution with bromine and a precipitate appeared due to the insoluble bromide during the experiment. Hence, the lipid is of marine oil (fish oil).

The muscle lipid of Cuttle fish was found to form treacle-like consistency with mercuric nitrate, $\mathrm{Hg}\left(\mathrm{NO}_{3}\right)_{2}$ solution after 24 hours during the experiment. Hence, the lipid is of semi-drying type. The amount of cholesterol in the muscle lipid of Cuttle fish was found to be $23.71 \mathrm{mg} / 100 \mathrm{~g}$. It can be suggested that the muscle lipid of Cuttle fish is more suitable for edible purpose with respect to its cholesterol level.

The effect of storage time on the lipid sample showed a significant variation in different values. Acid value, Peroxide value increased with increasing time of storage and RichertMeissl value, Thiocyaogen value, Titre value, Iodine value decreased with increasing time of storage. That means, the quality of the lipid deteriorated with increasing time of storage.

Table 3. Chemical constants of the muscle lipid of Cuttle fish and some other fats and oils.

\begin{tabular}{|c|c|c|c|c|c|c|c|c|c|c|c|c|c|c|}
\hline 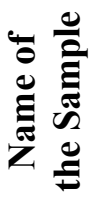 & $\overrightarrow{\dot{s}}$ & $\vec{j}$ & i & 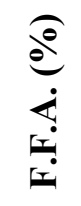 & $\vec{i}$ & 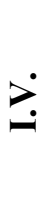 & نे & 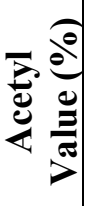 & $\stackrel{\dot{C}}{\vec{H}}$ & 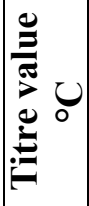 & $\dot{x}$ & $\underset{\dot{\rho}}{\stackrel{\dot{\rho}}{\dot{\rho}}}$ & 2 & 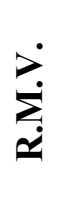 \\
\hline $\begin{array}{l}\overline{0} \\
. \bar{\partial} \\
. \overline{0}\end{array}$ & $\begin{array}{l}\stackrel{n}{a} \\
\stackrel{1}{\sigma}\end{array}$ & 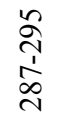 & $\begin{array}{l}n \\
\stackrel{n}{0} \\
\stackrel{0}{0}\end{array}$ & $\begin{array}{l}\text { ஸे : } \\
\\
0\end{array}$ & ' & $\begin{array}{l}\infty \\
\infty \\
\vdots \\
\infty\end{array}$ & I & $\stackrel{t}{\circ}$ & $\begin{array}{l}\tilde{\alpha} \\
\hat{1} \\
\vdots \\
\sim\end{array}$ & 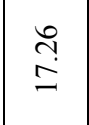 & $\stackrel{0}{0}$ & 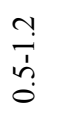 & $n$ & $\frac{n}{b}$ \\
\hline 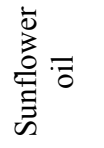 & $\begin{array}{l}\frac{+}{2} \\
\frac{1}{2}\end{array}$ & 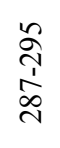 & $\begin{array}{l}\stackrel{+}{i} \\
\hat{b} \\
\stackrel{0}{0}\end{array}$ & 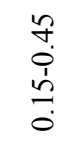 & ' & $\begin{array}{l}\stackrel{+}{ \pm} \\
\stackrel{1}{ }\end{array}$ & ' & i & 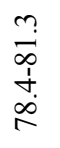 & $=$ & ' & $\begin{array}{l}\text { oे } \\
\text { ஸे } \\
\text { ò }\end{array}$ & ' & $\because$ \\
\hline
\end{tabular}




\begin{tabular}{|c|c|c|c|c|c|c|c|c|c|c|c|c|c|c|}
\hline $\begin{array}{l}\overline{0} \\
\bar{d} \\
\tilde{y} \\
\tilde{0} \\
\tilde{0} \\
0 \\
0\end{array}$ & 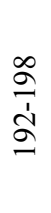 & 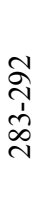 & $\begin{array}{l}0 \\
\dot{p} \\
0 \\
0\end{array}$ & $\begin{array}{l}0 \\
0 \\
\dot{1} \\
+ \\
0\end{array}$ & i & $\begin{array}{l}\text { 三 } \\
\text { ó } \\
\hat{0}\end{array}$ & i & $\frac{\widetilde{N}}{\frac{1}{\pi}}$ & $\begin{array}{l}\hat{0} \\
\frac{1}{6}\end{array}$ & ñ? & $\begin{array}{l}\text { İ } \\
\text {. }\end{array}$ & 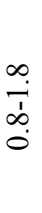 & I & ڤ̆ \\
\hline 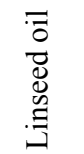 & $\frac{2}{\frac{1}{2}}$ & 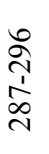 & $\stackrel{\circ}{+}$ & $\begin{array}{l}n \\
0 \\
0 \\
n \\
0\end{array}$ & i & 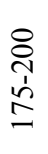 & i & i & I & i & $\begin{array}{l}\infty \\
\dot{\sigma}\end{array}$ & مُ & i & i \\
\hline 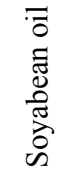 & $\frac{n}{\frac{1}{2}}$ & 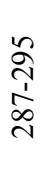 & 年 & $\begin{array}{l}n \\
\infty \\
0 \\
1 \\
n \\
n \\
0\end{array}$ & i & $\begin{array}{l}\frac{n}{2} \\
\text { ত̀ }\end{array}$ & 1 & I & $\begin{array}{l}n \\
\infty \\
1 \\
\\
2\end{array}$ & 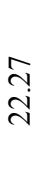 & 1 & $\frac{0}{\frac{1}{1}}$ & 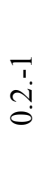 & $\begin{array}{l}n \\
n \\
n \\
n \\
0\end{array}$ \\
\hline 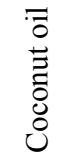 & 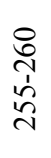 & 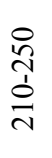 & $\begin{array}{l}\stackrel{0}{0} \\
\frac{1}{1} \\
\stackrel{\sim}{1}\end{array}$ & 1 & i & $\begin{array}{l}0 \\
\stackrel{a}{1} \\
\sim \\
\infty\end{array}$ & 1 & i & $\frac{\stackrel{0}{1}}{\frac{1}{6}}$ & $\begin{array}{l}\stackrel{+}{\sim} \\
\text { ٍे }\end{array}$ & $\infty$ & 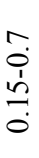 & $\frac{n}{n}$ & $\begin{array}{l}0 \\
\infty \\
\infty \\
\infty \\
\infty \\
r\end{array}$ \\
\hline 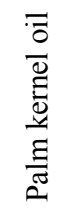 & $\stackrel{\infty}{\sim}$ & 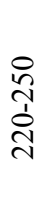 & 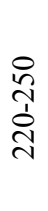 & i & i & $\frac{\infty}{n}$ & i & i & I & i & 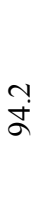 & i & i & $\stackrel{\infty}{\sim}$ \\
\hline 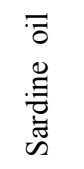 & $\begin{array}{l}\infty \\
\dot{\alpha} \\
\vdots \\
\infty \\
\infty \\
\infty\end{array}$ & ! & 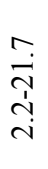 & I & i & 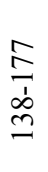 & I & I & I & I & I & i & I & i \\
\hline $\begin{array}{l}\overline{0} \\
\frac{0}{\pi} \\
\sum_{3}^{J}\end{array}$ & $\begin{array}{l}\stackrel{N}{1} \\
+ \\
\infty \\
-1\end{array}$ & ! & $\begin{array}{l}\vec{n} \\
\stackrel{n}{0}\end{array}$ & 1 & i & $\begin{array}{l}\hat{\jmath} \\
\text { i }\end{array}$ & I & i & I & i & I & i & 1 & i \\
\hline 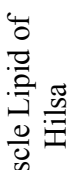 & 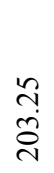 & $\begin{array}{l}\vec{\sigma} \\
\stackrel{0}{\sim} \\
\text { N }\end{array}$ & $\frac{\infty}{\stackrel{\infty}{\infty}}$ & $\begin{array}{l}\stackrel{n}{n} \\
n\end{array}$ & i & 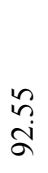 & $\begin{array}{l}n \\
i n \\
n\end{array}$ & 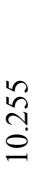 & $\begin{array}{l}\stackrel{+}{n} \\
\text { ñ }\end{array}$ & i & ઼ָ & $\stackrel{+}{\stackrel{0}{0}}$ & $\begin{array}{l}\vec{b} \\
\stackrel{0}{0}\end{array}$ & $\begin{array}{l}n \\
\stackrel{2}{0}\end{array}$ \\
\hline 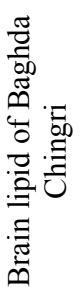 & 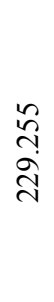 & 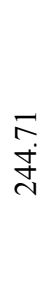 & $\exists$ & $\begin{array}{l}0 \\
n \\
n\end{array}$ & $\begin{array}{l} \pm \\
\stackrel{\infty}{\sim}\end{array}$ & $\begin{array}{l}\hat{\infty} \\
\hat{a}\end{array}$ & $\begin{array}{l}\check{a} \\
\dot{\Xi} \\
\Omega\end{array}$ & $\begin{array}{l}\infty \\
\stackrel{\infty}{?} \\
0\end{array}$ & $\begin{array}{l}\tilde{b} \\
\ddot{f}\end{array}$ & $\stackrel{\sim}{\sim}$ & $\begin{array}{l}\text { กै } \\
\stackrel{2}{2}\end{array}$ & $\begin{array}{l}8 \\
\stackrel{0}{0} \\
n \\
0\end{array}$ & $\begin{array}{l}\stackrel{2}{\circ} \\
0\end{array}$ & $\stackrel{ \pm}{\stackrel{ \pm}{-}}$ \\
\hline
\end{tabular}




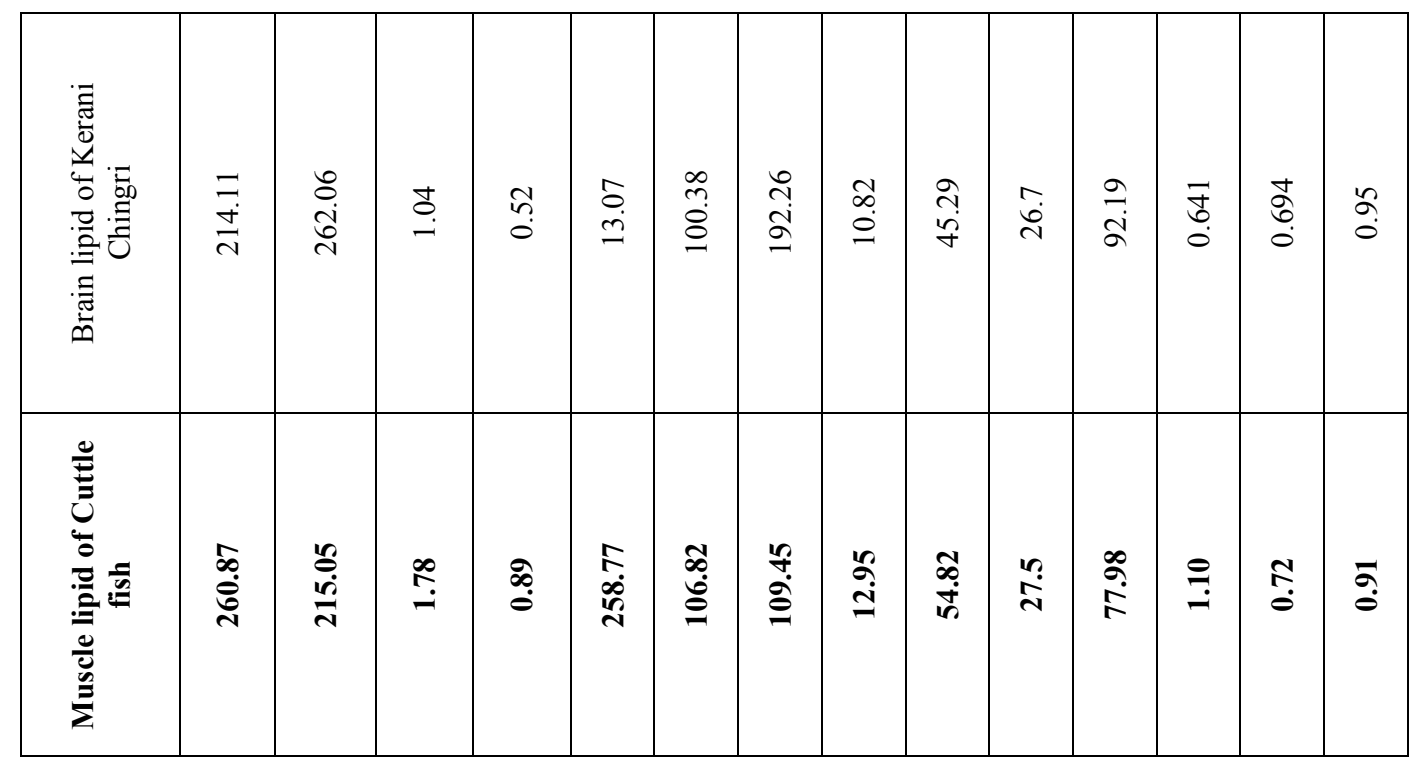

Abbreviations: S.V .= Saponification Value; S.E.V. = Saponification Equivalent Value; A.V. = Acid Value; F.F.A. = Free fatty acid; E.V. = ester value; I.V. = Iodine Value; P.O.V. = peroxide Value; T.V. = Thiocyanogen Value; H.V. = Henher Value; U.S.M. = Unsaponifiable Matter; P.V. = Polenske Value; R.M.V. = ReichertMeissl Value.

\section{3. Antimicrobial Activities}

In the present study, the lipid sample was selected and screened for antibacterial activities against four human pathogenic bacteria and antifungal activities against four phyto pathogenic fungi. It is evident from the Table 4 that, the lipid sample was found to be active against Salmonella typhi, Staphylococcus aureus, Escherichia coli and Bacillus cereus. Paper discs while soaked in lipid solution (10\%) was used, Salmonella typhi showed highest zone of inhibition for lipid sample $(21 \mathrm{~mm})$.

It is also evident from the Table 5 that the lipid sample did not show any inhibition on mycelial growth of Alternaria alternata. Except these mycelial growth of almost all test fungi was inhibited by the lipid sample. Fusarium equiseti showed highest zone of inhibition for the lipid sample (15.11 mm).

Table 4. Antibacterial activities of the muscle lipid of Cuttle fish.

\begin{tabular}{|c|c|c|c|c|}
\hline \multirow{2}{*}{$\begin{array}{c}\text { Name of } \\
\text { Bacteria }\end{array}$} & \multirow{2}{*}{$\begin{array}{c}\text { Type of } \\
\text { Sample }\end{array}$} & \multicolumn{3}{|c|}{$\begin{array}{c}\text { Zone of inhibition (diameter in mm) } \\
\text { after 48 hours }\end{array}$} \\
\cline { 3 - 5 } & & Treatment & Control & Differences \\
\hline \multirow{2}{*}{ Salmonella typhi } & $10 \%$ & 21 & 0 & 21 \\
& $5 \%$ & 10 & 0 & 10 \\
\hline Staphylococcus & $10 \%$ & 17 & 0 & 17 \\
aureus & $5 \%$ & 8 & 0 & 8 \\
\hline \multirow{2}{*}{ Escherichia coli } & $10 \%$ & 20 & 0 & 9 \\
\hline \multirow{2}{*}{ Bacillus cereus } & $5 \%$ & 9 & 0 & 16 \\
& $10 \%$ & 16 & 0 & 7.5 \\
\hline
\end{tabular}


Table 5. Percent growth inhibition of test fungi by the muscle lipid of Cuttle fish.

\begin{tabular}{|c|c|c|}
\hline \multirow{2}{*}{ Name of the Fungi } & $\begin{array}{c}\text { Type of } \\
\text { Sample }\end{array}$ & $\begin{array}{c}\text { Zone of inhibition (diameter in mm) } \\
\text { after 5 days }\end{array}$ \\
\cline { 3 - 3 } & & Muscle lipid of Cuttle fish \\
\hline Fusarium equiseti & $10 \%$ & 15.11 \\
\hline Aspergillus fumigateus & $10 \%$ & 6.10 \\
\hline Alternaria alternata & $10 \%$ & -10.76 \\
\hline Curvularia lunata & $10 \%$ & 3.45 \\
\hline
\end{tabular}

(-) means no inhibition.

\section{4. Estimation of $N, P, K$ and $C a$ in muscle of Cuttle fish}

Most of the people of our country have been suffering to a great extent from protein malnutrition. From the Table 6 , it is evident that Cuttle fish contains a good amount $(6.533 \%)$ of nitrogen as well as protein (proteineous nitrogen) which is well balance in respect of essential amino acids. The percentage of phosphorus (1.237) indicates that phospholipid may present in the lipid sample.

The percentage of potassium (1.118) in the lipid sample may be helpful to increase blood pressure for those people having low blood pressure. The percentage of calcium (0.450) may help formation of rigid bone structure of the community children in their growing age who eat this marine species.

Above all, the maximum catch and use of Cuttle fish should be encouraged for ready supply to different remote regions of Bangladesh as well all over the world under careful processing to avoid putrefaction.

Table 6. Percent of N, P, K and Ca in muscle of Cuttle fish.

\begin{tabular}{|c|c|c|c|c|}
\hline Name of the sample & N (\%) & P (\%) & K (\%) & Ca (\%) \\
\hline Brain lipid of Kerani Chingri & 3.090 & 0.5506 & 1.061 & 0.798 \\
\hline Brain lipid of Baghda Chingri & 3.540 & 0.7262 & 1.123 & 0.914 \\
\hline $\begin{array}{c}\text { Liver lipid of Blue Spotted Fantail } \\
\text { ray }\end{array}$ & 4.099 & 2.7500 & 1.180 & 0.641 \\
\hline \begin{tabular}{c} 
Muscle of Cuttle fish \\
\hline
\end{tabular} & 6.533 & 1.237 & 1.118 & 0.450 \\
\hline
\end{tabular}




\section{5. Chromatographic Analysis}

The muscle lipid of Cuttle fish was subjected to TLC examination and their fatty acid composition were identified by comparing the $\mathrm{R}_{\mathrm{f}}$ values of different spots of chromatograms with those standard fatty acids as reported (Table 7) in different solvent systems. It was found from the chromatograms that the lipids produced about 3-5 spots. Among the spots, four spots were identified as palmitic acid, stearic acid, linolenic acid and erucic acid in the muscle lipid of Cuttle fish.

Table 7. The $\mathrm{R}_{\mathrm{f}}$ values of thin layer chromatographic examination of the muscle lipid of Cuttle fish.

\begin{tabular}{|c|c|c|c|c|c|c|c|c|}
\hline \multirow{2}{*}{$\begin{array}{c}\text { Solvent } \\
\text { System }\end{array}$} & \multicolumn{2}{|c|}{$\mathbf{R}_{\mathbf{f}}$ values of standard fatty acids } & \multicolumn{3}{|c|}{$\begin{array}{c}\mathbf{R}_{f} \text { values obtained from the } \\
\text { chromatograms of lipid sample }\end{array}$} \\
\cline { 2 - 9 } & PA & SA & LA & EA & \multicolumn{2}{|c|}{} \\
\hline P:E (80:20) & 0.941 & 0.943 & 0.933 & 0.361 & 0.940 & 0.942 & 0.933 & 0.365 \\
\hline $\begin{array}{c}\text { P:E:A } \\
(80: 20: 1)\end{array}$ & 0.822 & 0.839 & 0.893 & 0.479 & 0.824 & 0.882 & 0.478 & 0.365 \\
\hline P:H (80:20) & 0.823 & 0.812 & 0.641 & 0.201 & 0.823 & 0.811 & 0.639 & 0.201 \\
\hline
\end{tabular}

PA-Palmitic Acid, SA-Stearic Acid, LA-Linoleic Acid, EA-Erucic Acid

\section{CONCLUSIONS}

Physico-chemical characterization and antimicrobial studies of muscle lipid of Cuttle fish (Sepia esculenta) have been done in this investigation. Large amount of unsaturated fatty acid presence in the lipid sample was confirmed by R.I., S.V., I.V. and T.V. Presence of sterols, tocopherols, vitamins A and D, is considered on the basis of U.S.M \% and low hydroxyl group content was confirmed by acetyl value of the sample. Percentage of F.F.A validated suitability of the oil for edible purpose. Chromatographic examinations substantiated the presence of some important $\omega-3$ PUFA in the muscle lipid. From antibacterial studies we can conclude that this work will provide valuable information about the prospect of derivation of antibiotics, pesticides and pharmaceutical components from the muscle lipid of Cuttle fish with further research. Protein and other important minerals $(\mathrm{Ca}, \mathrm{P}$ and $\mathrm{K}$ ) also found with significant values in the muscle of Cuttle fish.

\section{ACKNOWLEDGEMENT}

The authors are thankful to the Professor Dr. M. Abul Manchur, Department of Microbiology and Professor Dr. M. Nazim Uddin, Department of Chemistry, University of Chittagong for their generous help to perform some part of research work in their laboratories. This work was supported by the grants from Department of Chemistry, University of Chittagong, Bangladesh. 


\section{References}

[1] Q. S. Mohiduzzaman, M. M. Rahman, S. M. K. Ali, Bangladesh Med. Res. Council Bull. 20 (1994) 1-7.

[2] M. Ahmed, Text Book of Modem Biochemistry 1 (1991) 81.

[3] L. N. Siddique, M. S. Ali, S. S. Jahan, M. Muslemuddin, S. N. Begum, Bangladesh J. Pathology 9 (1994) 10-13.

[4] A. C. Deb, Fundamental Biochemistry $4^{\text {th }}$ ed. (1990) 55-56.

[5] B. S. Bahl, A. Bahl, Advanced Organic Chemistry 15 th ed. (2000) 644.

[6] R. C. Griffin, Technical Methods of Analysis, $2^{\text {nd }}$ ed, (1987) 199.

[7] R. T. Hanlon, J. B. Messenger, Philosophical Transactions of the Royal Society of London, 320 (2012) 437-487.

[8] J. E. Teitelbaum, W. A. Walker, Journal of Nutritional Biochemistry 12(1) (2001) 21-32.

[9] L. N. Siddique, M. S. Ali, S. N. Begum, M. Muslemuddin, S. S. Jahan, Bangladesh J. Physiol. Pharmacol. 11 (1995) 22-27.

[10] L. N. Siddique, M. S. Ali, S. N. Begum, S. S. Jahan, M. Muslemuddin, Journal of Dhaka Medical College 4 (1995) 13-17.

[11] M. N. Chowdhury, H. U. Rashid, H. Rahman, S. S. Jahan, M. R. Alam, M. Iqbal, Bangladesh Renal Journal 2 (2001) 14-19.

[12] S. Ranganna, Handbook of Analysis and Quality for Fruit and Vegetable Products, $2^{\text {nd }}$ ed. (1991) 3-226.

[13] A. J. Marshall. W. D. Williams, Textbook of Zoology Invertebrate, $7^{\text {th }}$ ed. (1995) 709-732.

[14] M. H. Uddin, M. A. Majid, Chittagong Univ. J. Science 24 (2000) 83-89.

[15] A. I. Vogel, A Text Book of Practical Organic Chemistry, (1975) 163.

[16] M. H. Uddin, M. A. Majid, A. C. Mistry, M. A. Manchur, Pakistan J. Sci. Ind. Res 41 (2004) 121-125.

[17] R. C. Griffin, Technical Method of Analysis, $2^{\text {nd }}$ ed., (1972) 309-342.

[18] J. B. Morris, The Chemical Analysis of Foods and Food Products, (1965) 375-382.

[19] S. Ranganna, Handbook of Analysis and Quality Control for Fruit and Vegetable Products, $2^{\text {nd }}$ ed. (1991) 3-226.

[20] K. A. Willams, Oils, Fats and Fatty Foods, $4^{\text {th }}$ ed. (1966) 124, 275, 329, 334, 356, 391. 
[21] S. Ahmed, M. S. Rahaman, J. U. Chowdhury, J. Begum, M. N. Anwar Chittagong Univ. J. Sci. 22 (1998) 77-81.

[22] I. M. M. Rahman, M. H. Uddin, M. W. Islam, M. A. Majid, Hamdard Medicus 52 (2009) 23-28.

[23] M. Loury, Rev. Franc. Corps. Gras. 11 (1966), 259-272.

[24] S. S. Jahan, H. K. Yusuf, S. Ahmed, $10^{\text {th }}$ Asian Conference on Diarrhoeal Diseases and Nutrition (ASCODD), Dhaka, Bangladesh, 7-9 Dec. (2003).

[25] L. G. Chatten, Pharmaceutical Chemistry 1 (1966) 423-424. 